\title{
Clinical and Bacteriological Study of Acute Tonsillitis
}

\author{
M.S.Vijayashree, , B.Viswanatha, B.N.Sambamurthy \\ Department of ENT, Bangalore medical college \& research institute Bangalore, INDIA
}

\begin{abstract}
Tonsillitis is inflammation of tonsils, a common clinical condition often encountered in E.N.T. practice. The management of this condition is often empirical with the choice of antibiotics not based on any culture reports. The increasing incidence of resistance in many organisms is due to $\beta$-lactamase production and resistance transfer factors that leads to unsuccessful medical therapy which results in recurrent or chronic forms of tonsillitis.

The present study was conducted to identify the prevalent bacterial pathogens and their antibiotic sensitivity that would indicate the optimum line of treatment and prevent the complications of acute tonsillitis and avoids unnecessary surgical treatment.
\end{abstract}

Key words: Acute tonsillitis, clinical study, bacteriological study

\section{Introduction}

Tonsillitis is inflammation of tonsils, a common clinical condition caused by either bacteria or viral infection. It affects significant percentage of population more so in children. The condition can occur occasionally or recur frequently. Acute tonsillitis is characterized by visible white streaks of pus on tonsils and the surface of the tonsils may become bright red colour. The bacterial tonsillitis is caused mainly by $\beta$ haemolytic Streptococcus, called strep throat and to lesser extent by Staphylococcus aureus and several other bacteria. The more common symptoms of tonsils are sore throat, red swollen tonsils, pain when swallowing, fever, cough, headache, tiredness, chills, swollen lymph nodes in the neck and pain in the ears or neck and the less common symptoms include nausea, stomach ache, vomiting, furry tongue, bad breath, change in voice and difficulty in opening of mouth.

The present study was conducted to identify the prevalent bacterial pathogens and their antibiotics sensitivity that would indicate the optimum line of treatment and prevent the complications of acute tonsillitis and avoids unnecessary surgical treatment.

\section{Materials and Methods}

The clinical and bacteriological study on acute tonsillitis was carried in the Department of ENT, Sri Venkateshwara ENT Institute, Bangalore Medical College \& Research Institute, Bangalore. The bacteriological work was carried out in the Department of Microbiology, Victoria Hospital, Bangalore.

Hundred cases of acute tonsillitis were selected at random from the patients attending the outpatient Department for a period of two years; each selected case has been studied as per the standard procedures. The chosen patients were not given antibiotics for one week prior to the study.

Specimens, one from the tonsillar surface and another from the cryptamagna were collected by using sterile cotton swabs, placed in sterile bottles aseptically, brought to the laboratory and subjected for direct microscopic examination of the pathogens followed by the isolation of the causal agents on different media viz., sheep blood agar, chocolate agar, Mc Conkey agar etc. The antibiotic sensitivity tests were done for all the isolated organisms. Antibiotics discs viz. penicillin, erythromycin, amphicillin, gentamycin, chloramphenicol, ciprofloxacin, cephalexin, cefotaxime, cephotaxime and amikacin were placed individually for all the isolates and the inhibition pattern was noted. After administering the antibiotics to patients as a remedy to treat tonsillitis, and after the complete cure, patients were followed up for six months or more to observe any recurrence tonsillitis. The data collected were analyzed with respect to age, sex, occupation, socioeconomic status, clinical manifestations and bacteriological results.

\section{Results}

The occurrence of acute tonsillitis with respect to population distribution was found to vary differently. Among the reported age groups, maximum tonsillitis cases were observed in the preteen age group (6-12 years) with $61 \%$ followed by teen age groups (12-18 years) $20 \%$, children (4-5 years) $10 \%$ and the least incidence of $9 \%$ in youth (19-30 years) (table $1 \&$ graph 1$)$. 
Table 1: Showing age distribution of patients

\begin{tabular}{|l|l|l|l|}
\hline Sl. No. & Age Group & No. of cases & Percentage \\
\hline 1 & 4-5 years & 10 & 10 \\
\hline 2 & 6-12 years & 61 & 61 \\
\hline 3 & $13-18$ years & 20 & 20 \\
\hline 4 & $19-30$ years & 09 & 09 \\
\hline
\end{tabular}

Graph 1: Showing age distribution of patients

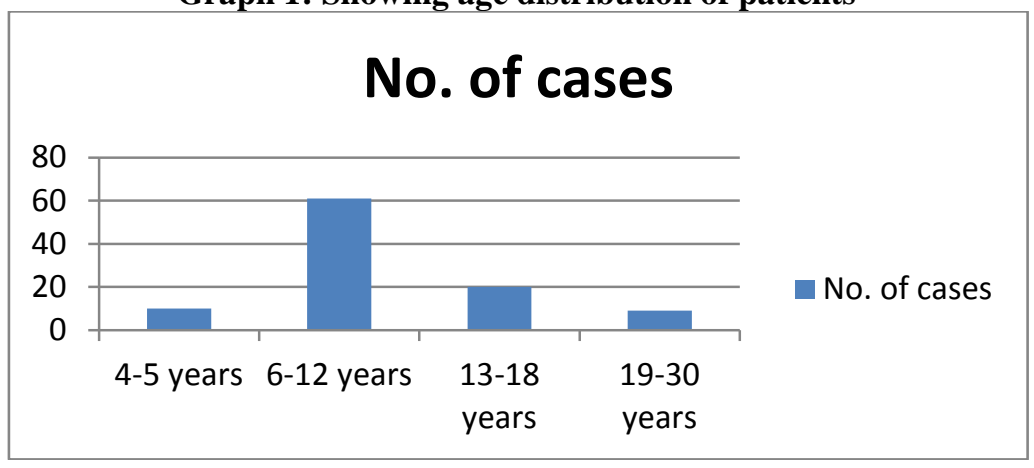

The distribution of tonsillitis was more in males patients (55\%) compared to female patients (45\%). As for as socioeconomic condition concerned, $61 \%$ of cases were observed in low income group, $35 \%$ in middle income group and a lowest occurrence of $4 \%$ in high income group (table2 \& graph 2).

Table 2: Showing socioeconomic status of patients

\begin{tabular}{|l|l|l|l|}
\hline Sl. No. & Sex & No. of cases & Percentage \\
\hline 1 & Low income group & 61 & 61 \\
\hline 2 & Middle income group & 35 & 35 \\
\hline 3 & Hi income group & 04 & 04 \\
\hline
\end{tabular}

Graph 2: Showing socioeconomic status of patients

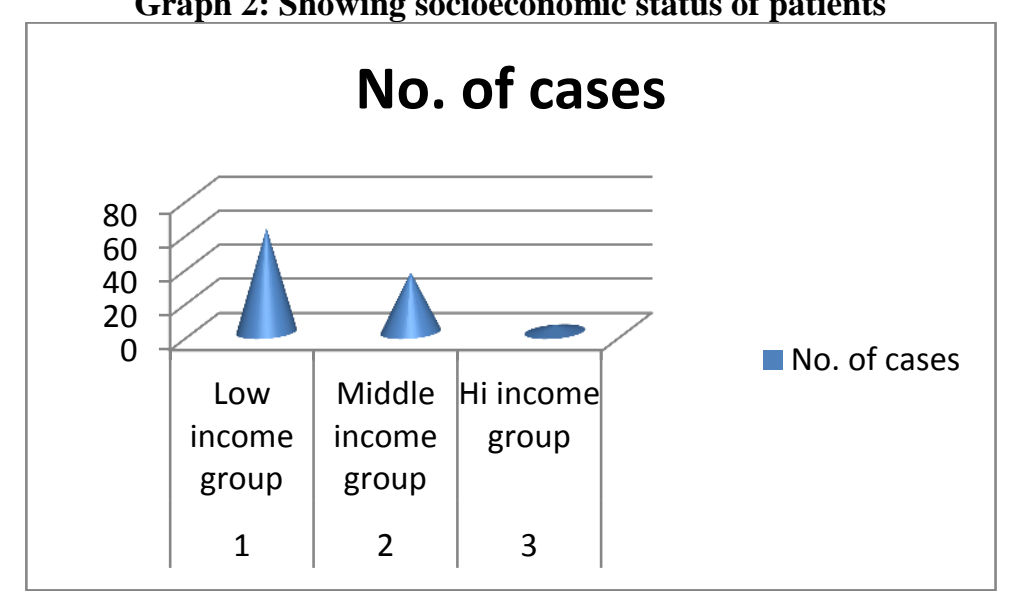

The incidence of the disease with regard to different occupations, it was noted that $70 \%$ of the patients, maximum cases belonged to student group, $15 \%$ homemakers, $8 \%$ labourers, $4 \%$ preschool children and minimum cases of $3 \%$ in businessmen group (table $3 \&$ graph 3 ).

Table 3: Showing occupational distribution of patients

\begin{tabular}{|l|l|l|l|}
\hline Sl. No. & Sex & No. of cases & Percentage \\
\hline 1 & Students & 70 & 70 \\
\hline 2 & Homemakers & 15 & 15 \\
\hline 3 & Labourers & 08 & 08 \\
\hline 4 & Petty businessmen & 03 & 03 \\
\hline 5 & Preschool children & 04 & 04 \\
\hline
\end{tabular}




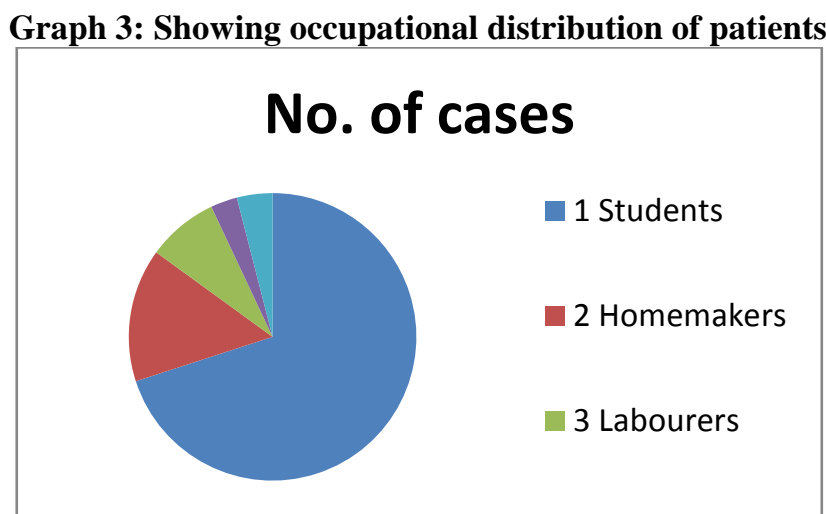

The occurrence of symptoms indicated that sore throat was observed in all the patients, fever in $73 \%$, odynophagia in $36 \%$ and constitutional symptoms in $45 \%$ of the patients (table $4 \&$ graph 4 ).

Table 4: Showing symptoms of patients

\begin{tabular}{|l|l|l|}
\hline Sl. No. & Age Group & Percentage \\
\hline 1 & Sore throat & 100 \\
\hline 2 & Fever & 70 \\
\hline 3 & Odynophagia & 31 \\
\hline 4 & Constitutional symptoms & 43 \\
\hline
\end{tabular}

Graph 4: Showing symptoms of patients

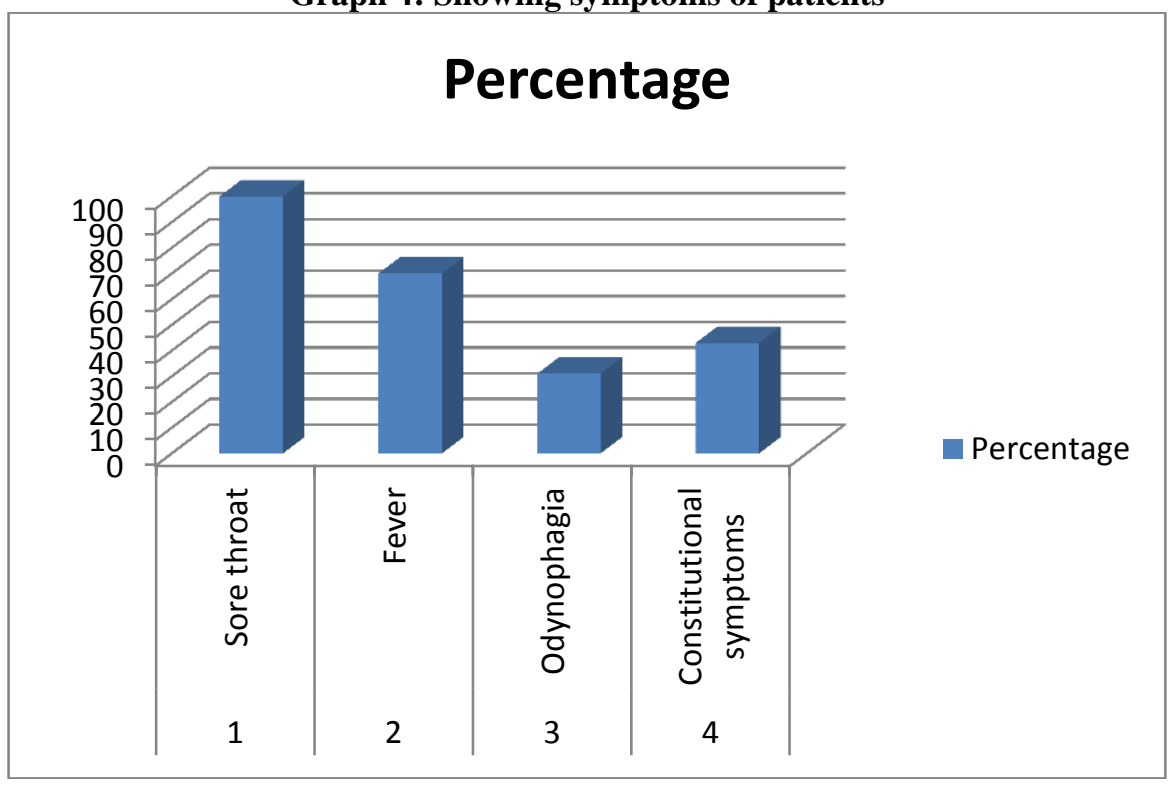

It was also observed that $59 \%$ of the patients exhibited acute paranchymatous tonsillitis signs, $40 \%$ acute follicular signs and only one per cent of the patients had acute membranous tonsillitis. The palpable tender digastrics lymph node was observed in $70 \%$ of the cases studied (table $5 \&$ graph 5).

Table 5: Showing signs of patients

\begin{tabular}{|l|l|l|}
\hline Sl. No. & Age Group & Percentage \\
\hline 1 & Acute paranchymatous & 59 \\
\hline 2 & Acute follicular & 40 \\
\hline 3 & Acute membranous & 01 \\
\hline 4 & Palpable tender lymph node & 70 \\
\hline
\end{tabular}




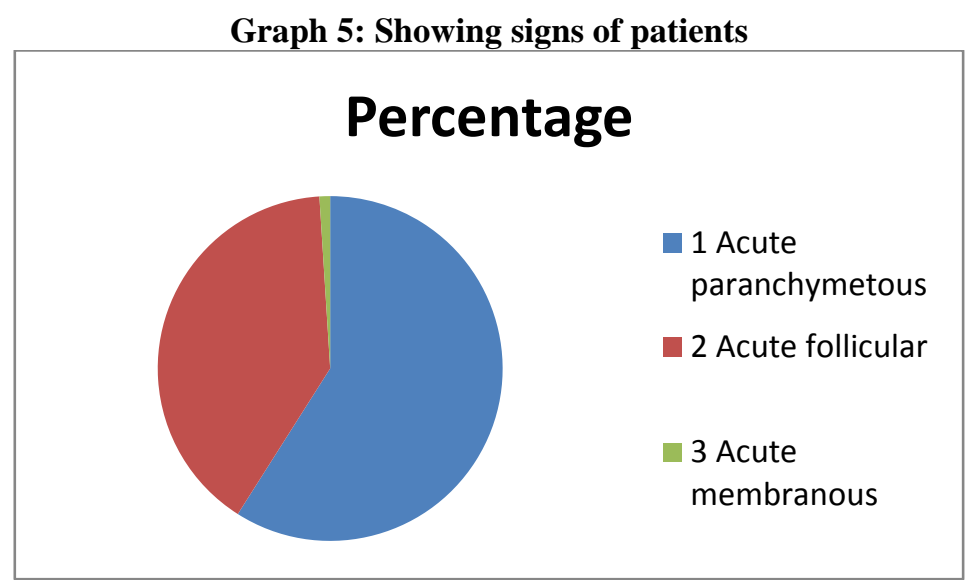

The bacteriological study of the throat swabs showed that $72 \%$ of the cases had pathogens, $10 \%$ had commensals, and however, no growth of bacteria was observed in $18 \%$ of the samples even after $48 \mathrm{~h}$ incubation on culture media. Among the bacteria isolated, $84.7 \%$ belonged to Gram positive group and only $15.3 \%$ belonged to Gram negative group (table 6 \& graph 6 ).

Table 6: Showing bacterial pathogens isolated from patients

\begin{tabular}{|l|l|l|l|}
\hline Sl. No. & Bacteria isolated & No. of cases & Percentage \\
\hline 1 & Pathogens & 72 & 72 \\
\hline 2 & Commensals & 10 & 10 \\
\hline 3 & No growth & 18 & 18 \\
\hline 4 & Gram +ve bacteria & 61 & 84.7 \\
\hline 5 & Gram -ve bacteria & 11 & 15.3 \\
\hline
\end{tabular}

Graph 6: Showing bacterial pathogens isolated from patients

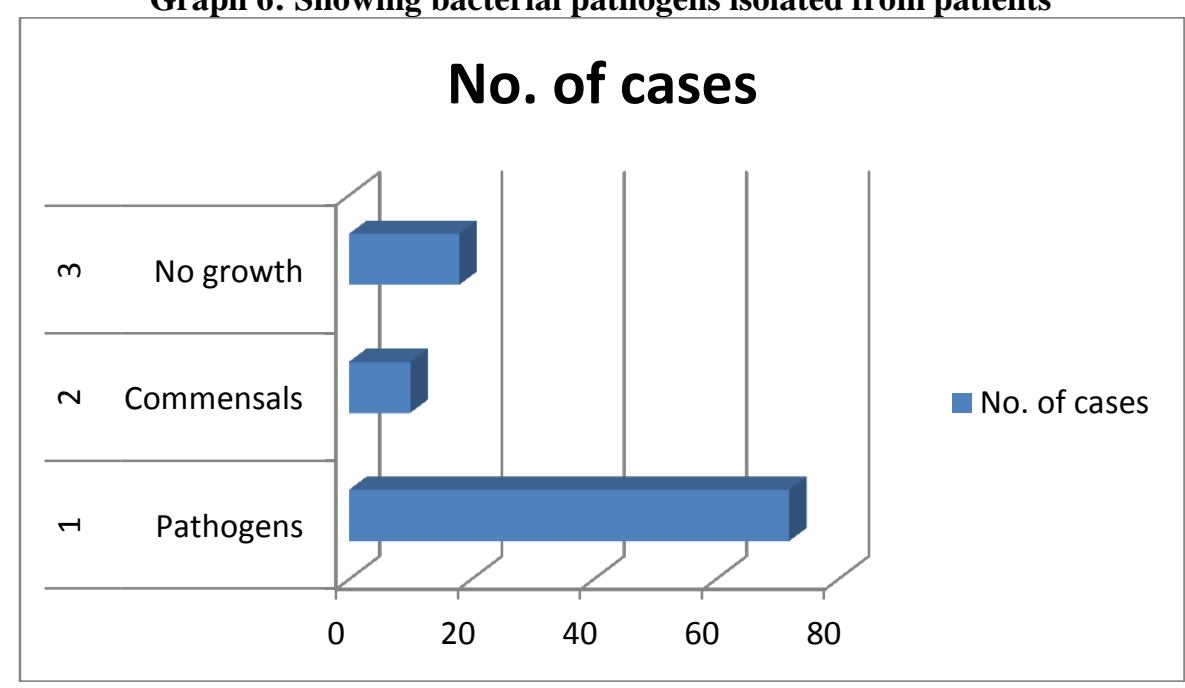

The bacteriological studies indicated the occurrence of predominant bacteria $\beta$ - haemolytic Streptococci (51.4\%), followed by co-agulase positive Staphylococci (12.5\%) and Pnemococci (9.7\%) and only one case of presence of Corynebacterium diphtheria was observed. With respect to monobacterial and polybacterial infections it was observed that $76.4 \%$ of the acute tonsillitis was caused by monobacterial infections as against polybacterial infections of $23.6 \%$. Where both Co-agulase positive Stahylococci and Pnemococci were observed in $8.3 \%$ cases and Klebsiella and Streptococus pyogens was observed in $6.9 \%$ cases and Pseudomonas sp was found to cause tonsillar infection along with Klebsiella in two cases (table7 \& graph 7). 
Table 7: Showing details of bacteria isolated from tonsillitis infected persons

\begin{tabular}{|l|l|l|l|}
\hline Sl. No. & Bacteria isolated & No. of cases & Percentage \\
\hline 1 & 3-hemolytic Streptococci & 37 & 51.4 \\
\hline 2 & Coagulase +ve Staphylococci & 9 & 12.5 \\
\hline 3 & Pnemococci & 7 & 9.7 \\
\hline 4 & Haemophilus influenza & 2 & 2.8 \\
\hline 5 & $\begin{array}{l}\text { Coagulase +ve Staphylococci \& } \\
\text { Pnemococci }\end{array}$ & 8.3 \\
\hline 6 & Klebsiella \& Streptococcus pyogens & 5 & 6.9 \\
\hline 7 & Pseudomonas \& Klebsiella & 2 & 2.9 \\
\hline 8 & $\begin{array}{l}\text { Pnemococci \& } \\
\alpha \text {-haemolytic Streptococci }\end{array}$ & 3 & 4.2 \\
\hline 9 & Corynebacterium diphtheria & 1 & 1.3 \\
\hline
\end{tabular}

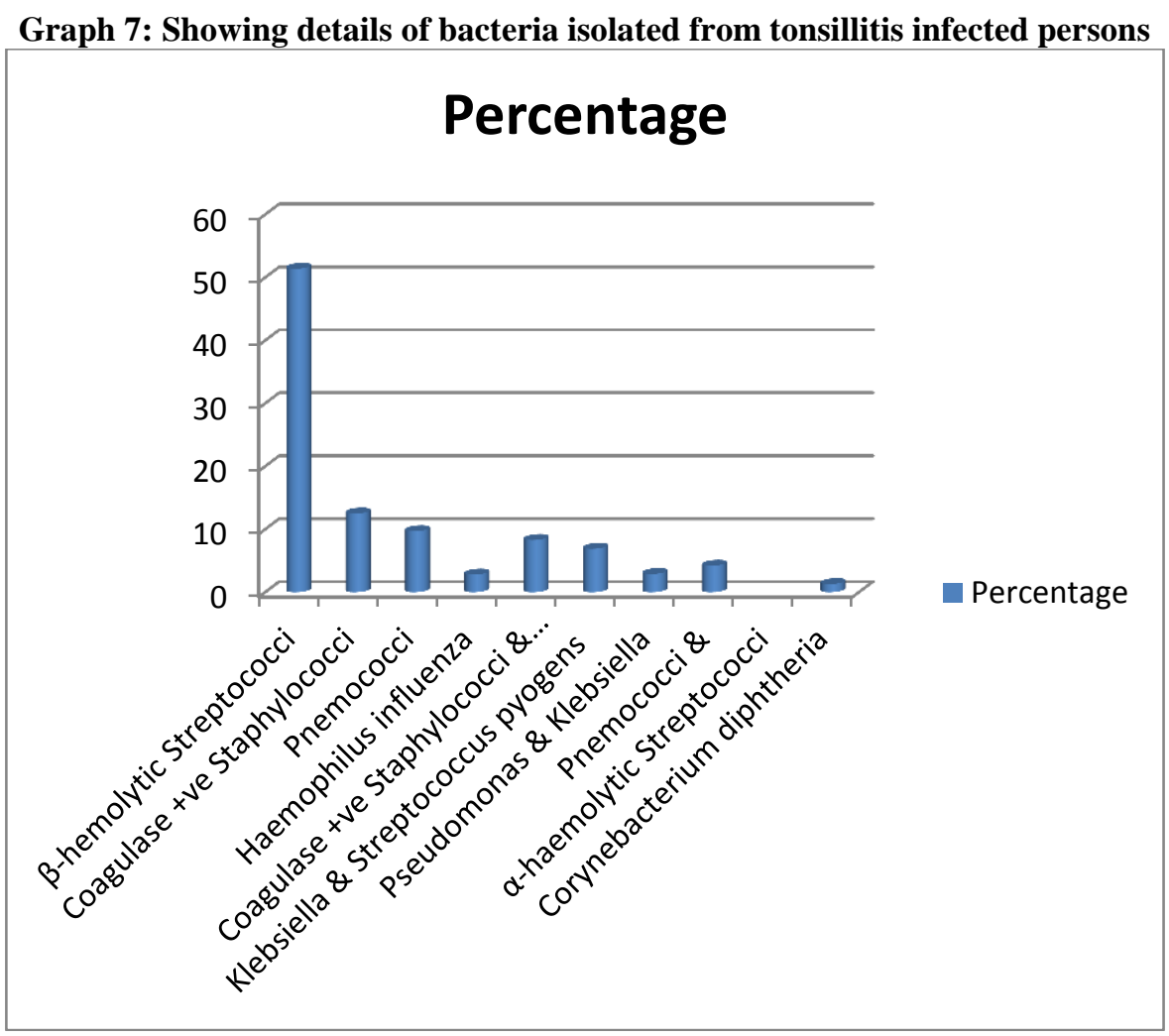

Sensitivity of isolated bacteria to different antibiotics and chemotherapeutic drugs indicated that Gram positive bacteria were more susceptible to antibiotics than Gram negative bacteria. Majority of the isolates were susceptible to antibiotics penicillin, erythromycin, amphicillin, gentamycin, chloramphenicol, ciprofloxacin, cephalexin, cefotaxime, cephotaxime and amikacin. Drug resistance was observed for 3 of the 9 co-agulase positive Staphylococci (table8).

Table 8: Showing antibiotic sensitivity assay of bacterial isolates

\begin{tabular}{|c|c|c|c|c|c|c|c|c|c|c|c|c|}
\hline \multicolumn{2}{|c|}{ Acute tonsillitis } & \multicolumn{9}{|c|}{ Sensitivity to antibiotics } & \multirow[b]{2}{*}{ 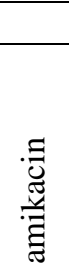 } & \multirow[b]{2}{*}{ on } \\
\hline $\begin{array}{l}\text { Sl. } \\
\text { No. }\end{array}$ & $\begin{array}{l}\text { Bacteria isolates } \\
(72)\end{array}$ & 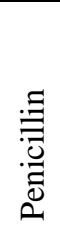 & 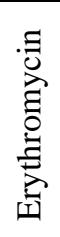 & 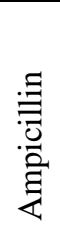 & 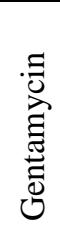 & 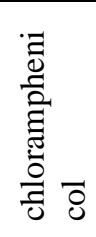 & 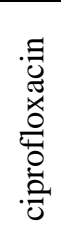 & 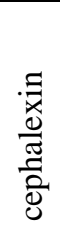 & 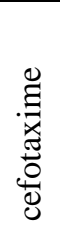 & 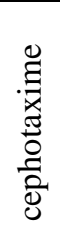 & & \\
\hline 1 & $\begin{array}{l}\beta \text {-hemolytic } \\
\text { Streptococci (37) }\end{array}$ & 35 & 30 & 35 & 6 & 30 & 15 & 30 & 35 & 35 & 30 & - \\
\hline
\end{tabular}




\begin{tabular}{|c|c|c|c|c|c|c|c|c|c|c|c|c|}
\hline & & & & & & & & & & & & \\
\hline 2 & $\begin{array}{l}\text { Coagulase +ve } \\
\text { Staphylococci } \\
\text { (9) }\end{array}$ & 6 & 4 & 6 & 5 & 6 & 4 & 6 & 6 & 6 & 4 & 3 \\
\hline 3 & Pnemococci (7) & 7 & 6 & 7 & 2 & 7 & 4 & 6 & 7 & 7 & 3 & - \\
\hline 4 & $\begin{array}{l}\text { Haemophilus } \\
\text { influenza (2) }\end{array}$ & 2 & $\mathrm{R}$ & 2 & $\mathrm{R}$ & 2 & 2 & $R$ & 2 & 2 & $\mathrm{R}$ & - \\
\hline 5 & $\begin{array}{l}\text { Coagulase +ve } \\
\text { Staphylococci \& } \\
\text { Pnemococci (6) }\end{array}$ & 4 & 4 & 4 & 3 & 4 & 3 & 5 & 5 & 5 & 3 & - \\
\hline 6 & $\begin{array}{l}\text { Klebsiella \& } \\
\text { Streptococcus } \\
\text { pyogens (5) }\end{array}$ & 1 & $\mathrm{R}$ & 1 & 4 & 2 & 4 & 5 & 5 & 5 & 4 & - \\
\hline 7 & $\begin{array}{l}\text { Pseudomonas \& } \\
\text { Klebsiella (2) }\end{array}$ & $\mathrm{R}$ & $\mathrm{R}$ & $\mathrm{R}$ & $\mathrm{R}$ & $\mathrm{R}$ & $\mathrm{R}$ & $\mathrm{R}$ & $\mathrm{R}$ & $\mathrm{R}$ & $\mathrm{R}$ & 2 \\
\hline 8 & $\begin{array}{l}\text { Pnemococci \& } \\
\alpha \text {-haemolytic } \\
\text { Streptococci (3) }\end{array}$ & 3 & 3 & 3 & 2 & 3 & 3 & 3 & 3 & 3 & 3 & - \\
\hline 9 & $\begin{array}{l}\text { Corynebacterium } \\
\text { diphtheria (1) }\end{array}$ & 1 & 1 & 0 & 1 & 1 & 1 & 0 & 1 & 1 & 0 & - \\
\hline
\end{tabular}

Follow up of the patients treated for the tonsillitis showed that the disease was recurred in $70.3 \%$ of the cases and not recurred in $27.6 \%$ of the patients. $2.1 \%$ of the patients developed peritonsillar abscess and they were treated with incision and drainage antibiotics (9).

Table 9: Showing post clinical status after the treatment of patients

\begin{tabular}{|l|l|l|l|}
\hline Sl. No. & Results & No. of cases & Percentage \\
\hline 1 & Recurrence & 66 & 70.3 \\
\hline 2 & No recurrence & 26 & 27.6 \\
\hline 3 & Peri tonsillar abscesses & 02 & 2.1 \\
\hline
\end{tabular}

\section{Discussion}

The occurrence of acute tonsillitis with respect to population distribution was found to vary differently. Among the reported age groups, maximum tonsillitis cases were observed in the preteen age group (6-12 years) with $61 \%$ followed by teen age groups (12-18 years) $20 \%$, children (4-5 years) $10 \%$ and the least incidence of $9 \%$ in youth (19-30 years). Similar observations were reported by Middleton et al $^{1}$ for the age group of 6-12 years. The distribution of tonsillitis was more in male patients (55\%) compared to female patients $(45 \%)$ probably because number of patients admitted were more than female patients. As for as socioeconomic condition concerned, $61 \%$ of cases were observed in low income group, $35 \%$ in middle income group and a lowest occurrence of $4 \%$ in high income group. The highest cases reported for low income group is perhaps due to their poverty, poor nourishment, unhygienic condition, illiteracy and improper medical care. The incidence of the disease with regard to different occupations, it was noted that $70 \%$ of the patients, maximum cases belonged to student group, $15 \%$ homemakers, $8 \%$ labourers, $4 \%$ preschool children and minimum cases of $3 \%$ in petty businessmen group. The reasons for such high incidence in school children may be due to low immunity in the children, cross infection because of overcrowded class rooms and poor ventilation of the class rooms.

The occurrence of symptoms indicated that sore throat was observed in all the patients, fever in $73 \%$, odynophagia in $36 \%$ and constitutional symptoms in $45 \%$ of the patients. Similar observations for sore throat and fever were reported by Evans and Dick ${ }^{2}$. It was also observed that $59 \%$ of the patients exhibited acute paranchymetous tonsillitis signs, $40 \%$ acute follicular signs and only one per cent of the patients had acute membranous tonsillitis. The palpable tender digastrics lymph node was observed in $70 \%$ of the cases studied. These observations are comparable to the findings of Veltri et $\mathrm{al}^{3}$.

The bacteriological study of the throat swabs showed that $72 \%$ of the cases had pathogens, $10 \%$ had commensals and however, no growth of bacteria was observed in $18 \%$ of the samples even after $48 \mathrm{~h}$ incubation 
on culture media. The reason for no growth is perhaps the patients would have administered the antibiotics prior to diagnosis or the tonsillitis was caused by virus which was not isolated in the study. Among the bacteria isolated, $84.7 \%$ belonged to Gram positive group and only $15.3 \%$ belonged to Gram negative group. As the gram positive bacteria are the normal colonisers of skin and other oral cavities, their number is probably found more than gram negative bacteria.

The bacteriological studies indicated the occurrence of predominant bacteria $\beta$ - hemolytic Streptococci (51.4\%), followed by co-agulase positive Staphylococci (12.5\%) and Pnemococci (9.7\%) and only one case of presence of Corynebacterium diphtheria was observed. These observations are in line with the earlier reported works of Surrow et $\mathrm{al}^{4}$. With respect to monobacterial and polybacterial infections it was observed that $76.4 \%$ of the acute tonsillitis was caused by monobacterial infections as against polybacterial infections of $23.6 \%$. Where both Co-agulase positive Stahylococci and Pnemococci were observed in $8.3 \%$ cases and Klebsiella and Streptococus pyogens was observed in $6.9 \%$ cases and Pseudomonas sp was found to cause tonsillar infection along with Klebsiella in two cases. Acute tonsillitis due to poly bacterial infection was reported by Brook et $\mathrm{al}^{5}$.

Sensitivity of isolated bacteria to different antibiotics and chemotherapeutic drugs indicated that Gram positive bacteria were more susceptible to antibiotics than Gram negative bacteria. Majority of the isolates were susceptible to antibiotics penicillin, erythromycin, amphicillin, gentamycin, chloramphenicol, ciprofloxacin, cephalexin, cefotaxime, cephotaxime and amikacin. Krober et ai $^{6}$. had showed penicillin to be the most effective antibiotic to treat tonsillitis caused by bacteria. Drug resistance was observed for 3 of the 9 co-agulase positive Staphylococci. The increasing incidence of drug resistance in many bacteria could be due to $\beta$ lactamase production by the bacteria that cleave the activity of antibiotics and resistance transfer factors that could have taken up by the susceptible strains during the recombination process.

Follow up of the patients treated for the tonsillitis showed that the disease was recurred in $70.3 \%$ of the cases and not recurred in $27.6 \%$ of the patients. $2.1 \%$ of the patients developed peritonsillar abscess and they were treated with incision and drainage antibiotics. Stafford et $\mathrm{al}^{7}$ have observed the recurrence of acute tonsillitis.

\section{Conclusions}

The present study conducted to identify the prevalent bacterial pathogens and their antibiotic sensitivity on patients of acute tonsillitis indicated that the bacterial infection is more prevalent in the age group of 6-12 years and it is more so with poor section of the society. Again it was observed that $\beta$ - hemolytic Streptococci to be the most predominant bacteria followed by co-agulase positive Staphylococci and Pnemococci bacteria responsible for tonsillitis infection and presence of Corynebacterium diphtheria was observed in one of the patients among the hundred patients subjected for the evaluation. The penicillin was found to be the effective drug to cure acute tonsillitis besides other antibiotics like ampicillin, cephalexin and cephotaxime, however, acute tonsillitis was found to recur $70.3 \%$ of the treated patients.

\section{Acknowledgements:}

Authors thank Dr.T.H.Shankarappa for his help in preparing this manuscript.

\section{References}

[1] Middleton DB, D’Amico F, Merenstein JH. Standardized symptomatic treatment vs penicillin as initial therapy Streptococcal pharyngitis. J. Pediatrics 1988; 113(6): 1089-1094.

[2] Evans AS, Dick EC. Acute pharyngitis and tonsillitis in University of Wisconsin students. JAMA 1964; 190 (8): 699-708.

[3] Veltry, RW, Sprinkle, PM, Mc Clugg JE. Epstein- Barr Virus associated with episodes of recurrent tonsillitis. Arch. Otolaryngol 1975; 101(9): 552-556.

[4] Surrow, JB, Handler SD, Telian SA, Fleisher GR, Baranak CC. Bacteriology of tonsil surface and core in children. Laryngoscope 1989; 99: 261-266

[5] Brook I, Yocum P, Friedman EM. Aerobic and anaerobic bacteria in tonsils of children with recurrent tonsillitis. Ann. Otol. Rhinol. Laryngol 1981; 90: 261-263.

[6] Krober MS, Bass JW, Michels GN. Streptococcal paryngitis- placebo controlled double blind evaluation of clinical response to penicillin therapy. JAMA.1985; 253(9): 1271-1274.

[7] Stafford N,VonHaacke N, Sene A, Croft C. 1986: The treatment of recurrent tonsillitis in adults. J. Laryngol. Otol 1986; 100 (2): $175-177$. 